\title{
Antioxidant Potential of Chestnut Shell, Stinging Nettle, Kiwi Fruit and Citrus Fruit Extracts and Antibacterial Effects Against Some Fish Pathogens
}

\author{
Orhan KOBYA $^{\mathbf{1}} \quad$ Büşra KARA ${ }^{\mathbf{1}} \quad$ Ecren UZUN-YAYLACI $^{*} \quad$ Emre ÇAĞLAK $^{\mathbf{1}}$ \\ ${ }^{l}$ Faculty of Fisheries and Aquatic Sciences, Recep Tayyip Erdoğan University, Rize, Turkey \\ ${ }^{2}$ Surmene Faculty of Marine Science, Karadeniz Technical University, Trabzon, Turkey
}

How to cite: Kobya, O., Kara, B., Uzun-Yaylacı, E. \& Çağlak, E. (2021). Antioxidant Potential of Chestnut Shell, Stinging Nettle, Kiwi Fruit and Citrus Fruit Extracts and Antimicrobial Effects Against Some Fish Pathogens. J. Anatolian Env. and Anim. Sciences, 6(2), 204-210.

Atıf yapmak için: Kobya, O., Kara, B., Uzun-Yaylacı, E. \& Cağlak, E. (2021). Kestane Kabuğu, Isırgan Otu, Kivi Meyvesi ve Narenciye Özütlerinin Antioksidan Potansiyelleri ve Bazı Balık Patojenlerine Karşı Antimikrobiyal Etkileri. Anadolu Çev. ve Hay. Dergisi,, 6(2), 204-210.

(iD): https://orcid.org/0000-0002-9788-4644 (iD) : https://orcid.org/0000-0002-6289-720X * (iD) : https://orcid.org/0000-0002-2558-2487

(iD): https://orcid.org/0000-0002-7376-1359

*Corresponding author's: Ecren UZUN-YAYLACI Karadeniz Technical University, Surmene Faculty of Marine Science, Trabzon, Turkey 凶: ecrenuzun@ktu.edu.tr

\begin{abstract}
The use of antioxidants and antibacterial compounds obtained from natural sources is important for human and animal health, as well as for controlling diseases. The aim of this study was to evaluates the antioxidant potentials and antibacterial effects of water extracts of $C$. sativa, U. dioica, A. deliciosa and C. aurantium against selected Gram-negative (Vibrio harveyi, Vibrio vulnificus, Vibrio anguillarum, Vibrio rotiferianus, Vibrio campbellii, Vibrio ponticus and Aeromonas veronii) and Gram-positive (Bacillus thuringiensis) bacteria. Results of antioxidant test indicated that the chestnut shell extract had the highest DPPH inhibition $(87.03 \%)$ followed by citrus fruit $(80.40 \%)$. All extracts showed antibacterial activity against one or more species of bacteria. The most susceptible bacteria were $V$. harveyi $(32.05 \mathrm{~mm}$ zone diameter) and $V$. campbellii (21.66 mm zone diameter) and the resistant species were $V$. anguillarum, $V$. ponticus and $A$. veronii. The results show that plant extracts have the potential to be used as an antibacterial agent in aquaculture and as an antioxidant agent in processing technology.
\end{abstract}

Keywords: antibacterial activity, antioxidant potential, pathogen bacteria, plant extracts.

\section{Kestane Kabuğu, Isırgan Otu, Kivi Meyvesi ve Narenciye Özütlerinin Antioksidan Potansiyelleri ve Bazı Balık Patojenlerine Karşı Antibakteriyel Etkileri}

*Sorumlu yazar:

Ecren UZUN-YAYLACI

Karadeniz Teknik Üniversitesi, Sürmene Deniz Bilimleri Fakültesi, Trabzon, Türkiye 凶: ecrenuzun@ktu.edu.tr

\begin{abstract}
Öz: Doğal kaynaklardan elde edilen antioksidan ve antimikrobiyal bileşiklerin kullanımı, insan ve hayvan sağlığı için olduğu kadar hastalıkların kontrolü açısından da önemlidir. Bu çalışmanın amac1, $C$. sativa, $U$. dioica, A. deliciosa ve $C$. aurantium bitkilerinden elde edilen su bazlı özütlerin antioksidan potansiyellerinin belirlenmesi, aynı zamanda seçilen Gram-negatif (Vibrio harveyi, Vibrio vulnificus, Vibrio anguillarum, Vibrio rotiferianus, Vibrio campbellii, Vibrio ponticus ve Aeromonas veronii) ve Gram-pozitif (Bacillus thuringiensis) bakterilere karşı antibakteriyel etkilerinin değerlendirilmesidir. Antioksidan aktivitesi testi sonuçlarına göre, en yüksek DPPH inhibisyonu $(\% 87,03)$ kestane kabuğu özütünde, ikinci olarak turunç özütünde $(\% 80,40)$ belirlenmiştir. Tüm özütlerin bir veya daha fazla bakteri türüne karş1 antibakteriyel aktivite gösterdiği tespit edilmiştir. Özütlere karş1 en duyarlı bakteriler $V$. harveyi $(32,05 \mathrm{~mm}$ zon çapı) ve $V$. campbellii $(21,66 \mathrm{~mm}$ zon çapı), dirençli türler ise $V$. anguillarum, $V$. ponticus ve $A$. veronii olarak belirlenmiştir. Çalışma sonuçları, elde edilen özütlerin su ürünleri yetiştiriciliğinde antibakteriyel madde ve işleme teknolojisinde antioksidan ajan olarak kullanılma potansiyeline sahip olduğunu göstermektedir.
\end{abstract}

Anahtar kelimeler: Antibakteriyel aktivite, antioksidan potansiyel, bitki özütü, patojen bakteri. 


\section{INTRODUCTION}

Antibiotic treatment has been applied for many years against bacterial diseases in aquaculture (Done et al., 2015). Continuous application of antibiotics causes the change of microbiota in aquaculture and can lead to evolving of antibiotic resistant bacteria (Resende et al., 2012; Akkan \& Çolaker, 2020; Akkan \& Topkaraoğlu, 2019 ). The occurrence of antibiotic resistant bacteria could have an adversely affect both natural environment and human health (Smith et al., 1994). Plant-based approaches have been widely used in veterinary and human medicine. Many plant extracts have a significant role in aquaculture (Çağlak \& Karslı, 2016; Direkbusarakom, 2004; Karsli et al., 2021).

Seafood has always maintained its importance in terms of nutrition due to its high protein content and the main source of polyunsaturated fatty acids (Bayrakl1 \& Duyar, 2021; Caglak \& Karsli, 2017). Besides these nutritional properties, it has a short shelf life (Karsli et al., 2019). Oxidation of fatty acids causes bitter taste and color changes (Kılınççeker, et al., 2009).

Plant sources may contain antioxidant and antimicrobial properties since it contains abundant phenolic substances (Karsli, 2021; Kolayli, et al., 2003; Rice-Evans et al., 1997). Antioxidants inhibit the formation of free radicals (FR) and reactive oxygen species (ROT). FR and ROTs damage the parts of the cell such as protein, fat, carbohydrate, and DNA, causing their structural properties to deteriorate. Antioxidants are substances that react very quickly with FR and ROTs and prevent autooxidation / peroxidation process (Karabulut \& Gülay, 2016). The antioxidant properties of various plant extracts are also used in studies on the preservation of food derived from seafood.

Castanea sativa is known chestnut and it belongs to the family of Fagaceae. Chestnut shell extracts show antioxidant activity (Vázquez et al., 2009) and leaves have antibacterial activity against bacterial strains because of their flavonoids (Basile et al., 2000). Urtica dioica L. is stinging nettle and it belongs to the family of Urticaceaea (Akgül, 1993). Nettle extracts have been used for traditional medicine because of their flavonoids, carotenoids, sterols, minerals, vitamins and amino acids (Baytop, 1999; Karabacak \& Bozkurt, 2008). Many studies have shown that nettle extracts have antioxidant (Matsingou et al., 2001) and antibacterial activity (Gülçin et al., 2004). Actinidia deliciosa is green kiwi fruit and is a member of the Actinidiaceae family (Al-Kawaz \& ALMashhady, 2016). Kiwi fruit contain high levels of antioxidants (Szeto et al., 2002). It is a source of vitamin C, dietary fibre, vitamin E, potassium (Nishiyama et al.,
2004) and bioactive compounds especially polyphenols (Park et al., 2006). Anzabi (2015) reported that kiwi fruit extracts have stronger antibacterial activity. Citrus aurantium L. belongs to Rutaceae family and is generally known as bitter orange (Azhdarzadeh \& Hojjati, 2016). Citrus fruits are an important source of antioxidants (Kang et al., 2006). They are rich in flavonoids (Suntar et al., 2018), ascorbic acid, phenolic compounds (Kamran et al., 2009), high fibre and vitamin contents and terpenes (Lario et al., 2004). Due to the abundance of many secondary metabolites bitter orange shows antibacterial properties (Kirbaşlar et al., 2009).

The use of antioxidants and antimicrobial compounds obtained from natural sources is important for human and animal health, as well as for controlling diseases. This current study was aimed to evaluates the antioxidant potentials and the in vitro antimicrobial activities of water extracts of $C$. sativa, $U$. dioica, A. deliciosa and $C$. aurantium against seven fish pathogenic bacteria for producing new antimicrobial agent of great benefit to aquaculture and preserving the high unsaturated fatty acids found in seafood.

\section{MATERIAL AND METHOD}

Plant material: The plant materials were collected in November-December 2019 from Northeast of Turkey and identified at the Department of Plant Biology of Recep Tayyip Erdoğan University (Table 1). Studies were conducted in the Faculty of Fisheries Seafood Processing Technology Laboratory.

Table 1. Characterization of chestnut, stinging nettle, kiwi fruit and bitter orange testing in present study.

\begin{tabular}{lccc}
\hline Plants Name & Scientific Name of Plant & Used Organ & Collecting Area \\
\hline Chestnut & Castanea sativa & Shell & Northeast of Turkey, Borçka, Artvin \\
Stinging nettle & Urtica dioica $L$. & Plant & Northeast of Turkey, Çarşbaşı, Trabzon \\
Kiwi & Actinidia deliciosa & Fruit Peel & Northeast of Turkey, Iyidere, Rize \\
Citrus & Citrus aurantium $L$. & Fruit Peel & Northeast of Turkey, Iyidere/Rize \\
\hline
\end{tabular}

Preparation of the extract: The collected fresh samples were dried in the oven at $60{ }^{\circ} \mathrm{C}$ for 24 hours, and then ground to a smaller $1 \mathrm{~mm}$ powder with the help of a laboratory-type grinder. 5 grams of sample powders were weighed and put into the Erlenmeyer flasks and $100 \mathrm{ml}$ of distilled water was added. Thus, the ratio of extracts was set to $5 \%$. The outside of the Erlenmeyer flask was covered with aluminum foil so as not to receive light and the probe of the ultrasonic homogenizer device was placed inside the flask. The conditions were adjusted as follows and the ultrasonic homogenizer was operated.

Device conditions: Time: 15 minutes, Temperature: $25^{\circ} \mathrm{C}$ (room temperature), Pulse: 5 seconds stroke / 5 seconds standby, Amplitude: $20 \%$. 
After the process applied with ultrasonic homogenizer, all samples were filtered with Whatman (no: 42) filter paper and the residues in the solution were removed from the extract. The extracts were filled into dark colored bottles and stored at $-80{ }^{\circ} \mathrm{C}$ until the analysis period.

Antioxidant activities: The antioxidant capacity of each sample was determined according to the Spectrophotometric DPPH (1,1-diphenyl-2picrylhydrazyl) free radical scavenging activity method (Brand-Williams \& Berset, 1995). In this method, proton transfer is realized mainly by antioxidant to DPPH free radical. As a result of the displacement of electrons, the initial purple-violet color turns yellow over time. The reaction rates of antioxidant substances with DPPH are different because the hydroxyl group in its chemical structure and molecular size are different. Spectrophotometric measurement was carried out at a wavelength of $517 \mathrm{~nm}$. The DPPH scavenging percentage calculated according to the following formula (Duh et al., 1999).

Percent inhibition $=\left[\left(\mathrm{A}_{0}-\mathrm{A}_{1}\right) / \mathrm{A}_{0}\right] \times 100$

$\mathrm{A}_{0}$ : absorbance of the control reaction

$\mathrm{A}_{1}$ : absorbance of the sample

Bacterial strains: Seven fish pathogenic bacterial strains were selected; Vibrio harveyi (NR 043165.1) Vibrio vulnificus (NR 036888.1), Vibrio anguillarum (NR 029254.1), Vibrio rotiferianus (NR 042081.1), Vibrio campbellii (MH231447.1), Vibrio ponticus (NR 029032.1) and Aeromonas veronii (NR 044845.1) all Gram-negative. Bacillus thrungiensis (NR 043403.1) was tested as Grampositive in the study. Strains from naturally infected fish Dicentrarchus labrax that were confirmed previously by Uzun \& Ogut (2015). All the bacterial strains were subcultured from the original culture in Mueller Hinton (MH) agar supplemented with $1.5 \% \mathrm{NaCl}$ at $24^{\circ} \mathrm{C}$ for $24 \mathrm{~h}$ was used for the antibacterial assay.

Antibacterial assay: The disc diffusion method was used to evaluate the antibacterial activity. Bacterial strains grown on $\mathrm{MH}$ agar supplemented with $1.5 \% \mathrm{NaCl}$ at $24{ }^{\circ} \mathrm{C}$ for $24 \mathrm{~h}$. The bacterial inoculum was suspended in a saline solution $(0.85 \% \mathrm{NaCl})$ and adjusted to a 0.5 McFarland standard turbidity $\left(10^{8} \mathrm{CFU} / \mathrm{ml}\right)$. Sterile discs (Whatman 2017-009) with the diameter of $6 \mathrm{~mm}$ were impregnated with $15 \mu \mathrm{L}$ of each extract and left to dry under laminar flow cabinet. Discs injected with $15 \mu \mathrm{L}$ of sterilized water served as negative controls. Test bacteria were streaked on MH Agar with a sterilized cotton swabs then the extract discs were positioned on the agar. The bacteria-streaked plates with the extract discs were incubated at $24^{\circ} \mathrm{C}$ for 2 days. Each extract was assayed in triplicate, independently. The diameter of the inhibition zone around each disc was measured with a digital caliper (Maher 16; with a precision of $0.1 \mathrm{~mm}$ ) and recorded.

Statistical analysis: To evaluate the data, variance analysis was performed using the JMP 5.0.1 (SAS) package program and the Tukey test was applied to the groups with differences.

\section{RESULTS AND DISCUSSION}

Antioxidant capacity: Numerous methods have been proposed to evaluate antioxidant activity and function (Gülçin et al., 2004). In this study, antioxidant activity of the water extract of $C$. sativa, $U$. dioica, A. deliciosa and $C$. aurantium were evaluated using free radical DPPH scavenging assay. DPPH assay is widely used for the evaluation of antioxidant activities of natural products (Duh et al., 1999). DPPH is characterized as a stable colored radical accepts an electron to become a stable diamagnetic molecule (Gülçin et al., 2004; Kedare \& Singh, 2011). It is a rapid, simple, inexpensive and widely used method for evaluating the activity of antioxidants. DPPH assay is spectrophotometric technique and shows a strong absorption band at $517 \mathrm{~nm}$. As can be seen in Figure 1, all extracts had an inhibitory effect on the DPPH radical.

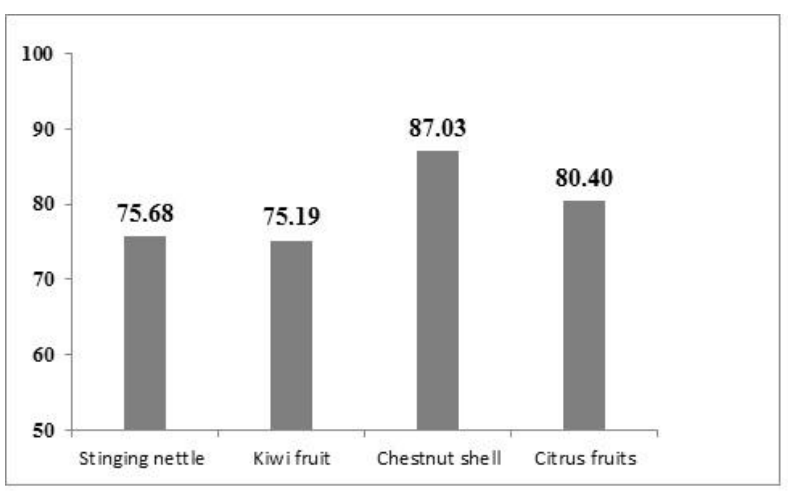

Figure 1. Antioxidant values (\% inhibition).

Chestnut inner shell was determined as the extract with the highest inhibition effect among the extracts examined in the study. Coccia et al. (2019) determined the antioxidant capacity of chestnut shell according to the DPPH method. They found the inhibition amounts of the extracts prepared with water and ethanol to be $74.3 \%$ and $79.8 \%$, respectively. Park et al. (2015) determined the amounts of antioxidants of kiwi fruit using DPPH method. They found the amount of inhibition of kiwi fruit at $92.9 \%$. Güder \& Korkmaz (2012) have identified the antioxidant amounts of extracts prepared by hydroalcoholic solution of the portions of nettle grass. They found the inhibition amounts of leaves, flowers and root extracts with a density of $250 \mu \mathrm{g} / \mathrm{mL}$ of nettle grass as $48.7 \%, 54.2 \%$ and $60.5 \%$, respectively. $\mathrm{Xu}$ et al., (2008) detected the antioxidant amount of orange juice by DPPH method. They found the 
amount of inhibition of orange juice at $69.36 \%$. When the antioxidant results of our study were examined, the inhibition amounts of nettle, orange and chestnut extracts were found to be higher than in the studies above. Park et al., (2015) in his study, the amount of inhibition of kiwi extraction was found to be higher than in our study. Differences between inhibition amounts; the method and rate of the extract used may affect factors such as environmental conditions of the plant.

Kılınççeker, (2014) determined in his study on the use of sage and nettle extracts in fish meatball coatings that the TBA amounts of all samples remained at an acceptable level until the last day of storage. Fernandez-Lopez et al., (2005) determined that the TBA values of meatballs with rosemary, lemon and orange oils were lower than the control group, and that essential oils had significant effects on the storage period. It has been shown in the literature that the antioxidant properties of stinging nettle, kiwi fruit, chestnut shell and citrus fruits extracts are beneficial in the field of seafood processing. In this regard, it is anticipated that these extracts can be beneficially used in seafood processing technology.

Antimicrobial activity: The antibacterial activity of the $C$. sativa, $U$. dioica, A. deliciosa and $C$. aurantium extracts was assessed against Gram-negative ( $V$. harveyi, $V$. vulnificus, $V$. anguillarum, $V$. rotiferianus, $V$. campbellii, $V$. ponticus and $A$. veronii) and Gram-positive (B. thuringiensis) bacteria. The evaluation of the antibacterial activity was realized by the disc diffusion testing. Table 2 illustrated that all extracts showed antibacterial activity against at least one of the reference strains. The most susceptible bacteria were $V$. harveyi and, $V$. campbellii and the resistant species were $V$. anguillarum, $V$. ponticus and $A$. veronii. From all the prepared extracts, the chestnut's inner shell was the most effective in suppressing microbial growth, as it was effective against 3 of the 8 bacteria tested, whereas the other three extracts showed variable antimicrobial activity were effective against only 2 or 3 bacteria each. The highest antibacterial potentiality extract was chestnut's inner shell, followed by the stinging nettle.

Table 2. Antibacterial activities (diameter of inhibition zone, $\mathrm{mm}$ ) of water extracts in disc diffusion assay.

\begin{tabular}{lcccccccc}
\hline \multirow{2}{*}{ Plant } & \multicolumn{8}{c}{ Inhibition zones (mm) } \\
\cline { 2 - 9 } & $\mathbf{1}$ & $\mathbf{2}$ & $\mathbf{3}$ & $\mathbf{4}$ & $\mathbf{5}$ & $\mathbf{6}$ & $\mathbf{7}$ & $\mathbf{8}$ \\
\hline C. sativa & 32.05 & ND & ND & 10.05 & 21.66 & ND & ND & ND \\
U. dioica L. & 18.44 & ND & ND & ND & ND & ND & ND & ND \\
A. deliciosa & ND & ND & ND & ND & 17.46 & ND & ND & ND \\
C. aurantium L & 14.66 & 9.56 & ND & ND & ND & ND & ND & 12.13 \\
\hline 1. V. harveyi; 2. V. vulnificus; 3. V. anguillarum; 4. V. rotiferianus; 5. V.campbellii; 6. V. ponticus; & 7. A. veronii; 8. B. thuringiensis; ND: zone diameter was not determined.
\end{tabular}

In this study, chestnut's shell extract is effective against Gram-negative bacteria, it was very effective in suppressing $V$. harveyi growth since it presented the larger inhibition zone. However, had no effect against Grampositive bacteria. It is known that lipopolysaccharide found in the surfaces of Gram-negative bacteria represent a major barrier for the entry of phenols into the cell cytoplasm (Fattouch et al., 2007; Martillanes et al., 2017). Nevertheless, V. harveyi, V. rotiferianus and V. campbellii were inhibited by chestnut's shell extract. This can be explained by the fact that chestnut shells have phenolic acids known to have antibacterial effect against Gramnegative bacteria (Silvia et al., 2020).

Modarresi-Chahardehi et al. (2012) reported that, string nettle extract had an antimicrobial effect on Vibrio parahaemolyticus and Bacillus subtilis. In present study, string nettle extract had an antimicrobial effect only against $V$. harveyi among Vibrio species but did not show any antibacterial activity against $B$. thrungiensis. Three reasons accounting for the different antibacterial activity of string nettle extract may be: extraction method, solvent and time. Because these differences may result in the release of different biological active components (alkaloids, flavonoids, essential oil, terpenoids, etc.) (Hanan et al., 2013). It is known that Citrus fruit extracts had antibacterial activity against microorganism. The study of Kirbaşlar et al. (2009) reported bitter orange extract had an antimicrobial effect both Gram- negative and Grampositive bacteria. Similarly, in this study bitter orange extract exhibit inhibitory activity against $V$. harveyi, $V$. vulnificus (Gram- negative) and B. thrungiensis (Grampositive). El-Kichaoi et al. (2015) reported that kiwi fruit extracted by water showed little antimicrobial activity both Gram- negative and Gram-positive bacteria. In our study A. deliciosa fruit extracts had an antimicrobial effect on only $V$. campbellii. All the extracts in the study were prepared with water. Although extracts prepared with ethanol provide stronger antimicrobial activity, water extracts also showed high antimicrobial activity in our study. This can be explained by the fact that the water extract was found to be richer in polar phenols than ethanol and methanol (Triantaphyllou et al., 2001), and this compound may be increasing the antimicrobial activity for water extracts (El-Kichaoi et al., 2015).

\section{CONCLUSION}

It is known that synthetic antioxidant and antimicrobial substances have negative effects on animals and humans. Therefore, interest in natural substances is increasing. With such studies, the antioxidant and antimicrobial activities of plant extracts can be determined and their potential for use in aquaculture and in processed seafood are evaluated. 
All plant extracts tested in this study had potential antibacterial activities against the reference strains. The chestnut inner shell extract with the highest DPPH inhibition also showed the highest zone diameters on agar. The results of the study support the use of these plants in the treatment of infectious diseases in aquaculture and for the prevention of fat oxidation in processed seafood technologies. In vitro, our results demonstrated the efficacy of these plant extracts in the inhibition of some pathogenic bacteria with an acceptable degree of effectiveness, but in vivo experiments are needed to confirm these results. The use of these extracts in different proportions in processed seafood and their introduction to industry should be improved.

\section{CONFLICT of INTERESTS}

The authors declare that there is no conflict of interests.

\section{REFERENCES}

Akgül, A. (1993). Spies science and technology. Association Food Technology Publ., 1993; No: 15. Ankara, Turkey.

Akkan, T. \& Çolaker, F. (2020). Determining the Bacteriological Pollution Level of Gelevera Creek, Giresun. Journal of Anatolian Environmental and Animal Sciences, 5(4), 691695. DOI: $10.35229 /$ jaes.818132

Akkan, T. \& Topkaraoğlu, T. (2019). Determination of antibiotic resistance levels of Escherichia coli isolates obtained from freshwater sources: Batlama Creek. Journal of Anatolian Environmental and Animal Sciences, 4(3), 539544. DOI: 10.35229/jaes.650210

Al-Kawaz, H.S. \& AL-Mashhady, L.A.M. (2016). Evaluation of the phytochemical constituents and oxidant - antioxidant status for Actinidia deliciosa extracts. International Journal of Pharmacy and Therapeutics, 7, 31-41.

Anzabi, Y. (2015). In Vitro Study of Berberis vulgaris, Actinidia deliciosa and Allium cepa L. antibacterial effects on Listeria monocytogenes. Crescent Journal of Medical and Biological Sciences, 2, 111-115.

Azhdarzadeh, F. \& Hojjati, M. (2016). Chemical composition and antimicrobial activity of leaf, ripe and unripe peel of bitter orange (Citrus aurantium) essential oils. Nutrition and Food Sciences Research, 3, 43-50. DOI: 10.18869/ACADPUB.NFSR.3.1.43

Basile, A., Sorbo, S., Giordano, S., Ricciardi, L., Ferrara, S., Montesano, D., Castaldo Cobianchi, R., Vuotto, M.L. \& Ferrara L. (2000). Antibacterial and allelopathic activity of extract from Castanea sativa leaves. Fitoterapia, 71, 110-116. DOI: 10.1016/s0367-326x(00)00185-4
Bayraklı, B. \& Duyar, H.A. (2021). Balık Unu Kalitesine Balık Tazeliğinin Etkisi; Hamsi Unu. Journal of Anatolian Environmental and Animal Sciences, 6(1), 57-65.

Baytop, T. (1999). Therapy with Plant in Turkey. Istanbul University, Faculty of Pharmacy (Second press). Nobel Medicine Bookstores, Istanbul, Turkey.

Brand-Williams, W.M.E. \& Berset, C. (1995). Use of a free radical method to evaluate antioxidant activity. LWT-Food Science and Technology, 28(1), 25-30. DOI: $10.1016 / \mathrm{S} 0023$ 6438(95)80008-5

Caglak, E. \& Karsli, B. (2017). Seasonal variation of fatty acid and amino acid compositions in the muscle tissue of zander (Sander lucioperca Linnaeus, 1758) and the evaluation of important indexes related to human health. Italian Journal of Food Science, 29(2), 266. DOI: 10.14674/11201770/ijfs.v576

Çağlak, E. \& Karslı, B. (2016). The effect of black seed oil and olive oil on shelf life of dry-salted crucian carp (Carassius carassius Linneaus, 1758). Iranian Journal of Fisheries Sciences, 15(4), 1624-1631.

Coccia, E., Siano, F., Volpe, M.G., Varricchio, E., Eroldogan, O.T. \& Paolucci, M. (2019). Chestnut shell extract modulates immune parameters in the rainbow trout Oncorhynchus mykiss. Fishes, 4, 18. DOI: 10.3390/fishes4010018

Direkbusarakom, S. (2004). Application of medicinal herbs to aquaculture in Asia. Walailak Journal of Science and Technology, 1, 7-14.

Done, H.Y., Venkatesan, A.K. \& Halden, R.U. (2015). Does the recent growth of aquaculture create antibiotic resistance threats different from those associated with land animal production in agriculture? American Association of Pharmaceutical Scientists Journal, 17, 513-524. DOI: 10.1208/s12248-015-9722-z

Duh, P., Tu, Y. \& Yen, G. (1999). Antioxidant activity of water extract of Harng Jyur (Chrysanthemum morifolium Ramat). Lwt-Food Science and Technology, 32, 269-277. DOI: 10.1006/fstl.1999.0548

El-Kichaoi, A., El-Hindi, M., Mosleh, F. \& Elbashiti, T. (2015). The antimicrobial effects of the fruit extracts of Punica granatum, Actinidia deliciosa and Citrus maxima on some human pathogenic microorganisms. American International Journal of Biology, 3, 63-75. DOI: 10.15640/aijb.v3n2a5

Fattouch, S., Caboni, P. \&Coroneo, V. (2007). Antimicrobial activity of Tunisian quince (Cydonia oblonga Miller) pulp and peel polyphenolic extracts. Journal of Agricultural and Food Chemistry, 55, 963-969. DOI: 10.1021/jf062614e

Fernández-López, J., Zhi, N., Aleson-Carbonell, L., Pérez-Alvarez, J.A. \& Kuri, V. (2005). Antioxidant and antibacterial activities of natural extracts: application in beef meatballs. Meat 
Science, $\quad 69, \quad 371-380 . \quad$ DOI: 10.1016/j.meatsci.2004.08.004

Güder, A. \& Korkmaz, H. (2012). Evaluation of in-vitro antioxidant properties of hydroalcoholic solution extracts Urtica dioica L., Malva neglecta Wallr. and their mixture. Iranian Journal of Pharmaceutical Research, 11, 913-923.

Gülçin, I., Küfrevioğlu, O.I., Oktay, M. \& Büyükokuroğlu, M.E. (2004). Antioxidant, antimicrobial, antiulcer and analgesic activities of nettle (Urtica dioica L). Journal of Ethnopharmacology, 90, 205-215. DOI: 10.1016/j.jep.2003.09.028

Hanan, B., Hijazi, A., Rammal, H., Hachem, A., Saad, Z. \& Badran, B. (2013). Techniques for the extraction of bioactive compounds from Lebanese Urtica dioica. American Journal of Phytomedicine and Clinical Therapeutics, 1, (6), 507-513.

Kamran, G., Youcef, G. \& Ebrahimzadeh, M.A. (2009). Antioxidant activity, phenol and fllavonoid contents of 13 Citrus species peels and tissues. Pakistan Journal of Pharmaceutical Sciences, 22, 277-281.

Kang, H.J., Chawla, S.P., Jo, C., Kwon, J.H. \& Byun, M.W. (2006). Studies on the development of functional powder from citrus peel. Bioresearch Technology, 97, 614-620. DOI: 10.1016/j.biortech.2005.03.037

Karabacak, S. \& Bozkurt, H. (2008). Effects of Urtica dioica and Hibiscus sabdariffa on the quality and safety of sucuk (Turkish dry-fermented sausage). Meat Science, 3, 288-296. DOI: 10.1016/j.meatsci.2007.06.013

Karabulut, H. \& Gülay, M.Ş. (2016). Antioxidants. Mehmet Akif Ersoy University Journal of Veterinary Faculty, 1, 65-76. DOI: 10.24880/maeuvfd.260790

Karsli, B., Caglak, E., Li, D., Rubio, N. K., Janes, M. \& Prinyawiwatkul, W. (2019). Inhibition of selected pathogens inoculated on the surface of catfish fillets by high molecular weight chitosan coating. International Journal of Food Science \& Technology, 54(1), 25-33. DOI: 10.1111/ijfs.13897

Karsli, B. (2021). Antibacterial and antioxidant activity of pulp, peel and leaves of Feijoa sellowiana: Effect of extraction techniques, solvents and concentration. Food and Health, 7(1), 21-30. DOI: $10.3153 / \mathrm{FH} 21003$

Karsli, B., Caglak, E. \& Kilic, O. (2021). Application of black cumin and green tea extracts and oils for microbiological, physicochemical, textural and sensorial quality of vacuum packaged rainbow trout fillets stored at $2 \pm 1^{\circ} \mathrm{C}$. Journal of Aquatic Food Product Technology. DOI: 10.1080/10498850.2021.1880511

Kedare, S.B. \& Singh, R.P. (2011). Genesis and development of DPPH method of antioxidant assay. Journal of Food Science and Technology, 48, 412-422. DOI: 10.1007/s13197-011-0251-1
Kılınççeker, O., Dogan, İ.S. \& Kucukoner, E. (2009). Effect of edible coatings on the quality of frozen fish fillets. LWT - Food Science and Technology, 42, 868-873. DOI: 10.1016/j.lwt.2008.11.003

Kılınççeker, O. (2014). The use of sage and stinging nettle extracts in edible coatings for fish meat balls. Adlyaman University Journal of Science, 4, 4756.

Kirbaşlar, F.G. Tavman, A., Dülger, B. \& Türker, G. (2009). Antimicrobial activity of Turkish citrus peel oils. Pakistan Journal of Botany, 41, 32073212.

Kolayli, S., Küçük, M., Duran, C., Candan, F. \& Dinçer, B. (2003). Chemical and antioxidant properties of Laurocerasus officinalis Roem. (Cherry laurel) fruit grown in the Black Sea region. Journal of Agricultural and Food Chemistry, 51, 7489-7494. DOI: $10.1021 /$ jf0344486

Lario, Y., Sendra, E., Garcı'a-Pe'rez, J., Fuentes, C., Sayas-Barberá, E., Fernández-López, J. \& Pérez-Alvarez, A.J. (2004). Preparation of high dietary fiber powder from lemon juice byproducts. Innovative Food Science and Emerging Technologies, $\quad 5, \quad 113-117 . \quad$ DOI: 10.1016/j.ifset.2003.08.001

Martillanes, S., Rocha-Pimienta, J., Cabrera-Bañegil, M., Martín-Vertedor, D. \& Delgado-Adámez, J. (2017). Application of phenolic compounds for food preservation: Food additive and active packaging. Phenolic Compounds - Biological Activity, 3(8), 39-58. DOI: 10.5772/66885

Matsingou, T.C., Kapsokefalou, M. \& Salifoglou, A. (2001). Aqueous infusions of mediterranean herbs exhibit antioxidant activity towards iron promoted oxidation of phospholipids, linoleic acid, and deoxyribose. Free Radical Research, 35, 593605. DOI: 10.1080/10715760100301601

Modarresi-Chahardehi, A., Ibrahim, D., FarizaSulaiman, S., Mousavi, L. (2012). Screening antimicrobial activity of various extracts of Urtica dioica. Revista de Biología Tropical, 60, 15671576.

Nishiyama, I., Yamashita, Y., Yamanaka M, Shimohashi A, Fukuda T, Oota T. (2004). Varietal difference in vitamin $\mathrm{C}$ content in the fruit of kiwifruit and other Actinidia species. Journal of Agricultural and Food Chemistry, 52, 5472-5475. DOI: 10.1021/jf049398z

Park, Y.S., Jung, S.T., Kang, S.G., Drzewiecki, J, Namiesnik, J., Haruenkit, R., Barasch D., Trakhtenberg, S. \& Gorinstein, S. (2006). In vitro studies of polyphenols, antioxidants and other dietary indices in kiwifruit (Actinidia deliciosa). International Journal of Food Sciences and Nutrition, 57, 107-122. DOI: 10.1080/09637480600658385

Park, Y.S., Im, M.H., Ham, K.S., Kang, S.G., Park, Y.K., Namiesnik, J., Leontowicz, H., Leontowicz, M., Trakhtenberg, S. \& Gorinstein, S. (2015). Quantitative assessment of the main antioxidant compounds, antioxidant activities and FTIR 
spectra from commonly consumed fruits, compared to standard kiwi fruit. LWT-Food Science and Technology, 63, 346-352. DOI: 10.1016/j.lwt.2015.03.057

Resende, J.A., Silva, V.L., Fontes, C.O., Souza-Filho, J. A., Rocha de Oliveira, T. L., Coelho, C. M., César, D. E. \& Diniz, C. G. (2012). Multidrugresistance and toxic metal tolerance of medically important bacteria isolated from an aquaculture system. Microbes Environments, 27, 449-455. DOI: 10.1264/jsme2.me12049

Rice-Evans, C., Miller, N. \& Paganga, G. (1997). Antioxidant properties of phenolic compounds. Trends in Plant Science, 2,152-159. DOI: 10.1016/S1360-1385(97)01018-2

Silva, V., Falco, V. \& Dias, M.I. (2020). Evaluation of the phenolic profile of Castanea sativa Mill. byproducts and their antioxidant and antimicrobial activity against multi resistant bacteria. Antioxidants (Basel), 9(1), 87. DOI: 10.3390/antiox9010087

Smith, P., Hiney, M.P. \& Samuelsen, O.B. (1994). Bacterial resistance to antimicrobial agent used in fish farming: a critical evaluation of method and meaning. Annual Review of Fish Diseases, 4, 273 313. DOI: 10.1016/0959-8030(94)90032-9

Szeto, Y.T., Tomlinson, B. \& Benzie, I.F. (2002). Total antioxidant and ascorbic acid content of fresh fruits and vegetables: implications for dietary planning and food preservation. The British journal of nutrition, 87, 55-59. DOI: 10.1079/BJN2001483

Suntar, I., Khan, H., Patel, S., Celano, R. \& Rastrelli, L. (2018). An overview on Citrus aurantium L.: Its functions as food ingredient and therapeutic agent. Oxidative Medicine and Cellular Longevity, Article ID7864269. DOI: $10.1155 / 2018 / 7864269$

Triantaphyllou, K., Blekas, G. \& Boskou, D. (2001). Antioxidative properties of water extracts obtained from herbs of the species Lamiaceae. International Journal of Food Sciences and Nutrition, 52, 313-317. DOI: $10.1080 / 09637480120057512$

Uzun, E. \& Ogut, H. (2015). The isolation frequency of bacterial pathogens from sea bass (Dicentrarchus labrax) in the Southeastern Black Sea. Aquaculture, 437, 30-37. DOI: 10.1016/j.aquaculture.2014.11.017

Vázquez, G., González-Alvarez, J., Santos, J., Freire, M.S. \& Antorrena, G. (2009). Evaluation of potential applications for chestnut (Castanea sativa) shell and eucalyptus (Eucalyptus globulus) bark extracts. Industrial Crops and Products, 2, 364-370. DOI: 10.1016/j.indcrop.2008.07.004

Xu, G., Liu, D., Chen, J., Ye, X., Ma, Y. \& Shi, J. (2008). Juice components and antioxidant capacity of citrus varieties cultivated in China. Food Chemistry, 106, 545-551. DOI: 10.1016/j.foodchem.2007.06.046 